\title{
Investigating the factors affecting postpartum diabetes screening in the patients with gestational diabetes mellitus: a reference tertiary center experience
}

\author{
Mefkure Eraslan Şahin' ${ }^{1}$ (D), Yusuf Madendağ ${ }^{2}$ (D) \\ ${ }^{1}$ Obstetrics and Gynecology Clinic, Kayseri City Hospital, Kayseri, Turkey \\ ${ }^{2}$ Department of Obstetrics and Gynecology, Faculty of Medicine, Erciyes University, Kayseri, Turkey
}

\begin{abstract}
Objective: The pregnant women with gestational diabetes mellitus (GDM) are under the risk of developing type 2 diabetes mellitus and cardiovascular disease after labor. The postpartum diabetes screening has a key role to establish the diagnosis of type 2 diabetes and to start necessary treatment at an earlier period. For that purpose, we aimed to investigate the rates of postpartum diabetes screening and the factors affecting these rates in the pregnant women with GDM diagnosis at Kayseri City Hospital which is a reference center.

Methods: This study was conducted retrospectively in a tertiary center by investigating pregnant women between 18 and 45 years old whose pregnancy follow-ups were done between June 2018 and January 2020. A total of 2652 pregnant women were screened for GDM by 75 -g oral glucose tolerance test (OGTT) during routine clinical follow-up and GDM was found in $425(16 \%)$ of these pregnant women. Of these 425 pregnant women, 225 who continued their postpartum follow-ups and whose contact information was accessed were included in the study. The patients were separated into two groups according to their preference of undergoing postpartum diabetes screening. The demographic characteristics, follow-up numbers and gestational complications of the groups were compared statistically.

Results: We found that only $34.6 \%$ (78/225) of the patients included in the study underwent postpartum diabetes screening and 147 $(65.4 \%)$ of them did not prefer to undergo postpartum screening. There was no difference between the groups in terms of maternal demographic characteristics. It was found that the patients underwent more postpartum diabetes screening tests in a statistically significant way in cases of the need for antenatal insulin treatment, antenatal visit number being $>10$ and the presence of antenatal complication $(\mathrm{p}<0.001, \mathrm{p}<0.001, \mathrm{p}<0.001$, respectively) which are among the gestational characteristics.

Conclusion: We found that only $34.6 \%(78 / 225)$ of the pregnant women with GDM diagnosis underwent postpartum diabetes screening, and the need for antepartum insulin treatment, antenatal visit number being more than 10 and the presence of antenatal complications were the important factors affecting screening rates. The patients with GDM should be informed again about the importance of undergoing postpartum diabetes particularly near the labor period and during discharge after labor and the type 2 diabetes risk should be explained in detail after labor.
\end{abstract}

Keywords: Gestational diabetes, diabetes screening, postpartum.

\begin{abstract}
Özet: Gestasyonel diabetes mellituslu hastalarda doğum sonrası diyabet taramasını etkileyen faktörlerin araştırılması: Bir referans üçüncül merkez deneyimi

Amaç: Gestasyonel diabetes mellituslu (GDM) gebeler doğumdan sonra tip 2 diabetes mellitus ve kardiyovasküler hastalık geliștirme riski altındadır. Doğum sonrası dönemdeki diyabet taraması, tip 2 diyabet tanısının erken dönemde konulması ve gerekli tedavinin erken dönemde başlanması için anahtar rol oynamaktadır. Bu nedenle bu çalışmada referans bir merkez olan Kayseri Şehir Hastanesinde GDM tanısı olan gebelerin, doğum sonrası dönemde diyabet taraması oranlarını ve bu oranları etkileyen faktörleri araştırmayı amaçladık.

Yöntem: Bu çalışma retrospektif olarak tersiyer bir merkezde, Haziran 2018 - Ocak 2020 arasında gebelik takibi yapılan 18-45 yas arası gebelerin değerlendirilmesi ile yapıldı. Rutin klinik takip sirasinda 2652 gebe $75-\mathrm{g}$ oral glukoz tolerans testi (OGTT) ile GDM açısından taranmıs olup bu gebelerden 425 'inde (\%16) GDM saptandı. $\mathrm{Bu} 425$ gebeden doğum sonrası takiplerine devam eden ve bilgilerine ulaşılan 225 gebe çalışmaya dahil edildi. Hastalar doğum sonu diyabet taramasını tercih edip etmediklerine göre iki gruba ayrıldı. Grupların demografik özellikleri, takip sayıları ve gebelik komplikasyonları istatistiksel olarak karşılaştırıldı.

Bulgular: Değerlendirmeye alınan gebelerin sadece \%34.6'sının $(78 / 225)$ doğum sonrası diyabet taraması yaptırdığı, 147'sinin (\%65.4) doğum sonrası tarama tercih etmediği tespit edildi. Gruplar arasında maternal demografik özellikler açısından fark yoktu. Gebelik özelliklerinden antenatal insülin tedavisi ihtiyacı olanlar, antenatal vizit sayısının $>10$ olması ve antenatal komplikasyon varlığinda (sırasiyla $\mathrm{p}<0.001, \mathrm{p}<0.001, \mathrm{p}<0.001$ ) hastaların istatistiksel olarak anlamlı derecede daha fazla doğum sonrası diyabet taraması yaptırdığı saptandı.

Sonuç: GDM tanılı gebelerin sadece \% 34.6'sının (78/225) doğum sonrası diyabet taraması yaptırdığını ve antepartum insülin tedavisi ihtiyaci, antenatal vizit sayısının 10'dan fazla olması ve antenatal komplikasyon varlığının tarama oranlarını etkileyen önemli faktörler olduğunu tespit ettik. GDM'li hastalarda özellikle doğuma yakın ve doğum sonrası taburculuk sırasında tekrar doğum sonrası diyabet taraması yaptırması vurgulanmalı ve Tip 2 diyabet riski ciddi bir şekilde doğum sonrası anlatılmalıdır.
\end{abstract}

Anahtar sözcükler: Gestasyonel diyabet, diyabet taraması, postpartum.

Correspondence: Yusuf Madendağ, MD. Department of Obstetrics and Gynecology, Faculty of Medicine, Erciyes University, Kayseri, Turkey. e-mail: yusufmadendag@gmail.com / Received: May 1, 2020; Accepted: June 12, 2020

Please cite this article as: Eraslan Şahin M, Madendağ Y. Investigating the factors affecting postpartum diabetes screening in the patients with gestational diabetes mellitus: a reference tertiary center experience. Perinatal Journal 2020;28(2):95-100. doi:10.2399/prn.20.0282011 


\section{Introduction}

Gestational diabetes mellitus (GDM) is the glucose intolerance starting at the second and third trimesters of the pregnancy and it is one of the most common poor outcomes of pregnancy. ${ }^{[1]}$ GDM incidence has been increasing globally as a result of the increase of obesity and maternal age, and it causes a great economic burden on the public healthcare system. ${ }^{[1-3]}$ The perinatal complications associated with GDM include cesarean section, shoulder dystocia, preterm labor, macrosomia, birth trauma, stillbirth and neonatal hypoglycemia. ${ }^{[4]}$ In addition, the women with GDM are under the risk of developing type 2 diabetes mellitus and cardiovascular disease after labor. ${ }^{[5]}$ The GDM prevalence varies between $1.2 \%$ and $27.9 \%$ in various studies conducted in Turkey regionally. ${ }^{[6]}$ Type 2 diabetes may be found in about half of these patients diagnosed with GDM many years after pregnancy. ${ }^{[7]}$ The study bulletins of American Diabetes Association (ADA) and American College of Obstetricians and Gynecologists (ACOG) recommend type 2 diabetes screening via preprandial plasma glucose or 2-hour oral glucose tolerance test (OGGT) at postpartum 4-12 weeks after GDM diagnosis. ${ }^{[8,9]}$ The diabetes screening at postpartum period has a key role to establish early diagnosis of type 2 diabetes and to start necessary treatment at an earlier period. The association of undiagnosed and untreated diabetes with microvascular and macrovascular complication risk was reported. ${ }^{[10]}$ It was reported in the literature that there is lack of information for postpartum screening in the pregnant women with GDM in addition to the lack of time and motivation and that additional support is needed to reach these goals. ${ }^{[11,12]}$ The programs supporting lifestyle changes after GDM may decrease the development risk of type 2 diabetes later. ${ }^{[13]}$ In the light of these information, we aimed to investigate the rates of postpartum diabetes screening and the factors affecting these rates in the pregnant women who were diagnosed with GDM at Kayseri City Hospital which is a reference center.

\section{Methods}

This study was conducted retrospectively to evaluate the pregnant women between 18 and 45 years old whose pregnancy follow-ups were carried out at the Obstetrics and Gynecology Clinic of Kayseri City Hospital between June 2018 and January 2020. All stages of the study were conducted in accordance with the Declaration of
Helsinki, and its ethical approval was obtained from the Ethics Committee of Erciyes University. A total of 2652 pregnant women were screened for GDM by $75-\mathrm{g}$ OGTT during routine clinical follow-up and GDM was found in 425 (16\%) of these pregnant women. In accordance with the routine approach of our clinic, all pregnant women with GDM are discharged by recommending type 2 diabetes screening via preprandial plasma glucose or 2-hour OGTT at postpartum 4-12 weeks. Of these 425 pregnant women, 225 who continued their postpartum follow-ups at Kayseri City Hospital and whose contact information was accessed were included in the study. The patients were separated into two groups according to their preference of undergoing postpartum diabetes screening. The flow chart of the patients is shown in Fig. 1.

The patients who were diagnosed with type 1 and type 2 diabetes previously, those with the history of endocrine diseases affecting carbohydrate metabolism (Cushing disease, Addison's disease, hypopituitarism, acromegalia, etc.) or the patients using drugs that may affect their blood sugar levels (steroids, etc.) were excluded from the study. The last menstrual date was used to

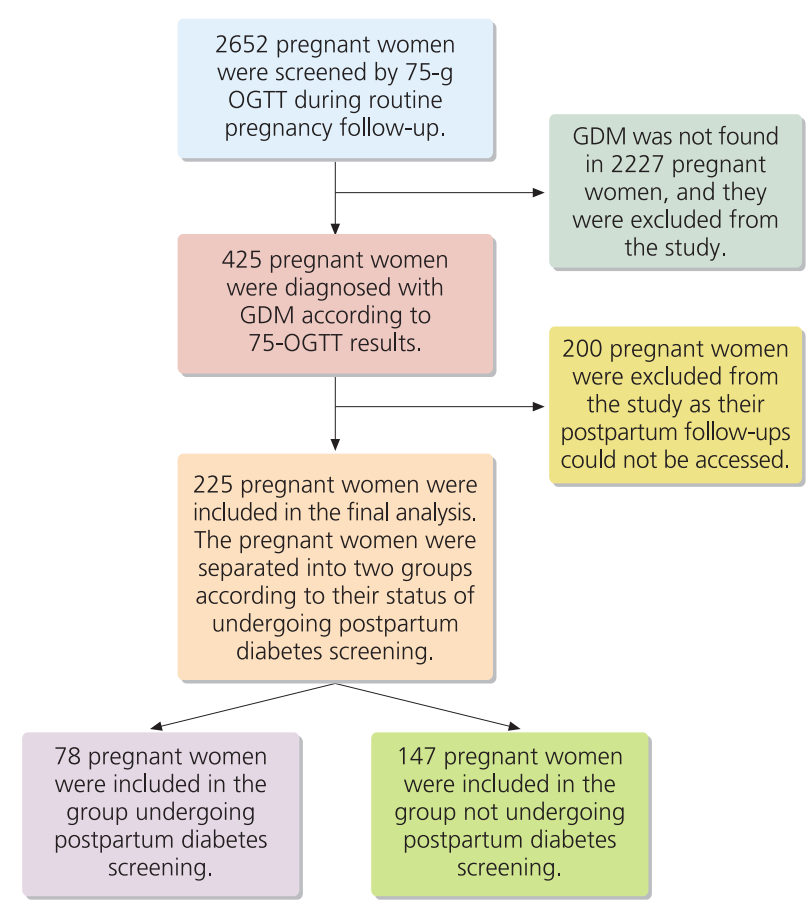

Fig. 1. The flow chart of the patients. 
Table 1. The comparison of the maternal demographic characteristics between the groups.

\begin{tabular}{lccc} 
Demographic characteristics & $\begin{array}{c}\text { The group undergoing postpartum } \\
\text { diabetes screening }(\mathbf{n = 7 8 )}\end{array}$ & $\begin{array}{c}\text { The group not undergoing postpartum } \\
\text { diabetes screening (n=147) }\end{array}$ & $\begin{array}{c}\text { p-value } \\
\text { Maternal age (year) }\end{array}$ \\
\hline $\mathrm{BMl}>30 \mathrm{~kg} / \mathrm{m}^{2}$ & $32.35 \pm 2.66$ & $32.95 \pm 2.85$ & 0.126 \\
\hline Ethnicity (Caucasian) & $20(25.6 \%)$ & $39(26.5 \%)$ & 0.885 \\
\hline Parity & $71(91.0 \%)$ & $135(91.8 \%)$ & 0.835 \\
\hline Previous cesarean delivery & $3(2-5)$ & $3(2-5)$ & 0.436 \\
\hline Family history of diabetes & $18(23.0 \%)$ & $41(21.7 \%)$ & 0.822 \\
\hline
\end{tabular}

The values are presented as median (min-max), mean \pm standard deviation, and $\mathrm{n}(\%)$. BMI: body mass index.

determine the weeks of gestation of the patients. The gestational ages of those with unknown last menstrual date were calculated according to the ultrasonographic measurements. The patients were screened by one-step 75-g OGTT, and the criteria of IADPSG (The International Association of Diabetes and Pregnancy Study Groups) were used for the diagnosis. ${ }^{[14]}$ The Guidelines of Turkish Perinatal Society recommends 75-g OGTT for each pregnant woman and those consent the test as we have a risky ethnic group. ${ }^{[7]}$ After 12hour fasting, plasma glucose of the patients were measured, and then $75 \mathrm{~g}$ glucose was administered orally. The venous blood samples were collected one and two hours later. The upper limits of fasting state and first and second hours plasma glucose values following glucose intake were 91, 179 and $152 \mathrm{mg} / \mathrm{dL}$, respectively. ${ }^{[15]}$ Any value above the threshold values was considered as positive test. GDM prevalence was determined according to the results of this one-step screening test. Chronic hypertension, gestational hypertension, preeclampsia, fetal growth restriction, macrosomia and polyhydramnios were defined as poor perinatal outcomes.

The data were analyzed by using Minitab 16 (Minitab Inc., State College, PA, USA) to compare the groups. Shapiro-Wilk test was used to determine the normality of data and to compare two groups. The assumption of homogeneity of variance was tested by Levene's test. The values were presented as mean \pm standard deviation and $\mathrm{n}(\%)$. Parametric comparisons were done by Student-t test and non-parametric comparisons were done by Mann-Whitney $U$ test. Percentage and $n$ values were analyzed by using Pearson's chi-squared test. When the difference between the groups was $\mathrm{p}<0.05$, it was considered statistically significant.

\section{Results}

A total of 225 pregnant women were evaluated in the study. Of these cases, 78 (34.6\%) were included in the group referring for postpartum diabetes screening and $147(65.4 \%)$ were included in the group not preferring postpartum diabetes screening. The maternal demographic characteristics of two groups are shown in Table 1. The groups were similar when they were compared for the mean maternal age $(\mathrm{p}=0.126)$, body mass index $>30 \mathrm{~kg} / \mathrm{m} 2$ values $(\mathrm{p}=0.885)$, ethnicity $(\mathrm{p}=0.835)$, parity $(\mathrm{p}=0.436)$, previous cesarean delivery $(\mathrm{p}=0.822)$ and the rates of family history of diabetes $(\mathrm{p}=0.877)$. The gestational characteristics of the groups were compared in Table 2, and it was found that the patients underwent more postpartum diabetes screening tests in a statistically significant way in cases of the need for antenatal

Table 2. The comparison of the gestational characteristics between the groups.

\begin{tabular}{lcc} 
Gestational characteristics & $\begin{array}{c}\text { The group undergoing postpartum } \\
\text { diabetes screening (n=78) }\end{array}$ & $\begin{array}{c}\text { The group not undergoing postpartum } \\
\text { diabetes screening (n=147) }\end{array}$ \\
\hline Need for antenatal insulin treatment & $23(29.4 \%)$ & $26(17.6 \%)$ \\
\hline Antenatal visit number $>10$ & $69(88.4 \%)$ & $<15(78.2 \%)$ \\
\hline Presence of antenatal complications* & $26(33.3 \%)$ & $<0.001$ \\
\hline
\end{tabular}

*Chronic hypertension, gestational hypertension, preeclampsia, fetal growth restriction, macrosomia and polyhydramnios. The values are presented as $\mathrm{n}$ (\%). 
Table 3. The comparison of labor characteristics between the groups.

\begin{tabular}{lccc} 
Labor characteristics & $\begin{array}{c}\text { The group undergoing postpartum } \\
\text { diabetes screening }(\mathbf{n = 7 8})\end{array}$ & $\begin{array}{c}\text { The group not undergoing postpartum } \\
\text { diabetes screening }(\mathbf{n = 1 4 7 )}\end{array}$ & $38(37-39)$ \\
\hline Week of gestation during labor (week) & $38(37-39)$ & $80(54.4 \%)$ & 0.952 \\
\hline Labor induction & $45(57.6 \%)$ & $65(44.2 \%)$ & 0.850 \\
\hline Spontaneous vaginal delivery & $36(46.1 \%)$ & $3300 \pm 150$ & 0.784 \\
\hline Fetal weight at birth (g) & $3350 \pm 170$ & $83(56.4 \%)$ & 0.920 \\
\hline Fetal male sex & $42(53.8 \%)$ & 0.740 \\
\hline
\end{tabular}

The values are presented as median (min-max), mean \pm standard deviation, and $n(\%)$.

insulin treatment, antenatal visit number being $>10$ and the presence of antenatal complication $(\mathrm{p}<0.001$, $\mathrm{p}<0.001$, and $\mathrm{p}<0.001$, respectively). The labor characteristics of the patients are presented in Table 3, and it was found that the week of gestation during labor $(\mathrm{p}=0.952)$, need for labor induction $(\mathrm{p}=0.850)$, spontaneous vaginal delivery rates $(\mathrm{p}=0.784)$, fetal weight $(\mathrm{p}=0.920)$ and fetal male sex rates $(\mathrm{p}=0.740)$ were similar when the groups were compared.

\section{Discussion}

Postpartum OGTT is an important approach in the management of the pregnant women diagnosed with GDM, and it is known that the likelihood of developing type 2 diabetes is seven times higher in women with GDM history than the women without GDM history throughout their lives. ${ }^{[7]}$ These women are also under the risk of early diabetes in their next pregnancies. Ekelund et al. reported in their study that $51 \%$ of the patients with GDM have impaired glucose tolerance and $30 \%$ of them develop type 2 diabetes within 5 years. ${ }^{[16]}$ Many clinical studies showed that it is possible to decrease or delay diabetes incidence among women with high disease risk with the help of diet and exercise or a pharmacological agent during postpartum period. ${ }^{[17-19]}$

Considering the results of our study, we did not find any correlation between postpartum diabetes screening and maternal age, body mass index, ethnicity, parity, previous cesarean delivery and the presence of family history of diabetes. In addition, there was no correlation between postpartum diabetes screening and the week of gestation during delivery, labor induction, spontaneous vaginal delivery rates, fetal weight and fetal sex. We found that the patients underwent more postpartum diabetes screening tests in cases of the need for antenatal insulin, antenatal visit number being more than 10 and the presence of antenatal complication. We found out that only $34.6 \%(78 / 225)$ of the pregnant women underwent postpartum diabetes screening. Werner et al. evaluated 300 patients diagnosed with GDM in their prospective study, and they reported that $42 \%$ of the pregnant women underwent postpartum diabetes screening, and educational status, income level, mothers having a job and the use of insulin during pregnancy were the factors affecting the screening. ${ }^{[20]}$ Similar to our results, the authors did not find any correlation between postpartum diabetes screening and maternal age, parity, ethnicity, family history of diabetes, delivery type, delivery characteristics and fetal outcomes. In another study investigating postpartum diabetes screening, Korkmazer et al. evaluated 738 pregnant women with GDM and reported that only $30.7 \%$ of the pregnant women completed postpartum diabetes screening. They also showed that $65.9 \%$ of the patients did not know screening test, and $19.1 \%$ of them did not apply for the test due to financial difficulties and $7.8 \%$ of them due to family problems. ${ }^{[21]}$ Bennett et al. reported that only $6-11 \%$ of the pregnant women underwent postpartum diabetes screening within the first 3 months after labor and $15-21 \%$ of them underwent the screening test within the 1 year after labor. ${ }^{[22]}$ It was reported in the USA that less than $20 \%$ of women with GDM underwent diabetes screening by OGTT within the first 6 months after labor. ${ }^{[23,24]}$

The following question comes to mind considering the current screening rates: Why do not these patients come back for diabetes screening test after labor? Traditionally, pregnant women concern about potential fetal complications in the presence of GDM and they do not skip their antenatal follow-ups; however, the disappearance of these concerns after labor cause failures in 
postpartum follow-ups. It is reported that the most of women with GDM perceived themselves as healthy and did not need to undergo the test or were afraid of the diagnosis and therefore avoided the screening. ${ }^{[2,25,26]}$ In addition, there are studies reporting that the training of pregnant women diagnosed with GDM during the postpartum period may be insufficient considering the restrictions of intense clinic practices. ${ }^{[2,27]}$

The number of studies aiming to develop postpartum diabetes screening increases gradually. In their study, Hunt et al. explained the necessity of postpartum OGTT to the patients by contacting them at least three times during postpartum period via a managing nurse who provides postpartum training and follows up the patients in a population with the postpartum diabetes screening rate of $18 \%$. All patients interacted with this case manager nurse at least three times during pregnancy and right after labor, and the laboratory needs for postpartum OGTT were met. The case manager nurse contacted the patients who did not visit for OGTT once more and conducted the OGTT test at home when necessary. Yet, 400 (57\%) of 707 women come back for postpartum visit, but 288 (41\%) of them did not complete OGTT. ${ }^{[28]}$ Similarly, Stasenko et al. retrospectively investigated the impact of educational intervention on the postpartum diabetes screening in the women with GDM. In this study conducted with the diabetes trainer, postpartum patients received consultancy for 3 months, and the authors reported that the rate of undergoing postpartum preprandial plasma glucose or OGTT increased from $33.4 \%$ to $52.7 \% .{ }^{[29]}$ In 2014 , MendezFigueroa et al. defined a program for the postpartum period in order to define the patients with GDM and arrange test appointments, follow up the completion of the test, provide reminders for participation and reschedule the missed appointments with the help of a special nurse or social support official working with the patients directly. When the authors compared the postpartum diabetes screening rates before and after the program, they found that the screening rates increased from $43.1 \%(78 / 181)$ to $59.4 \%(123 / 217){ }^{[30]}$

\section{Conclusion}

Considering the results of our study, we found that only $34.6 \%(78 / 225)$ of the pregnant women underwent postpartum diabetes screening, and the need for antepartum insulin treatment, antenatal visit number being more than 10 and the presence of antenatal complications were the important factors affecting screening rates. The patients with GDM should be informed about the importance of undergoing postpartum diabetes particularly near the labor period and during discharge after labor and the type 2 diabetes risk should be explained in detail after labor.

Conflicts of Interest: No conflicts declared.

\section{References}

1. American Diabetes Association. (2) Classification and diagnosis of diabetes. Diabetes Care 2015;38 Suppl:S8-S16. [PubMed] [CrossRef]

2. Zhu Y, Zhang C. Prevalence of gestational diabetes and risk of progression to type 2 diabetes: a global perspective. Curr Diab Rep 2016;16:7. [PubMed] [CrossRef]

3. Sahin E, Col Madendag I, Sahin ME, Madendag Y, Acmaz G, Muderris II. Effect of vitamin D deficiency on the $75 \mathrm{~g}$ oral glucose tolerance test screening and insulin resistance. Gynecol Endocrinol 2019;35:535-8. [PubMed] [CrossRef]

4. Metzger BE, Lowe LP, Dyer AR, Trimble ER, Chaovarindr U, Counstan DR, et al.; HAPO Study Cooperative Research Group. Hyperglycemia and adverse pregnancy outcomes. N Engl J Med 2008;358:1991-2002. [PubMed] [CrossRef]

5. Bellamy L, Casas JP, Hingorani AD, Williams D. Type 2 diabetes mellitus after gestational diabetes: a systematic review and meta-analysis. Lancet 2009;373:1773-9. [PubMed] [CrossRef]

6. Sahin ME, Madendag IC. Evaluation of the prevalence of gestational diabetes mellitus in Kayseri city hospital: A cross-sectional study. J Surg Med 2019;3:715-7. [CrossRef]

7. Şen C, Yayla M, Api O, Yapar Eyi EG, Ülkümen BA. Diabetes in pregnancy: diagnosis and treatment. Practice Guidelines of Turkish Perinatology Society. Perinatal Journal 2016;24:110 27. [CrossRef]

8. American Diabetes Association. 13. Management of diabetes in pregnancy: standards of medical care in diabetes-2018. Diabetes Care 2018;41(Suppl 1):S137-43. [PubMed] [CrossRef]

9. Committee on Practice Bulletins-Obstetrics. ACOG practice bulletin no. 190: Gestational diabetes mellitus. Obstet Gynecol 2018;131:e49-e64. [PubMed] [CrossRef]

10. Soffer MD, Factor SH, Rosenman A, Levy C, Stone J. Improving postpartum glucose monitoring in women with gestational diabetes. J Matern Fetal Neonatal Med 2017;30: 3014-9. [PubMed] [CrossRef]

11. Van Ryswyk E, Middleton P, Shute E, Hague W, Crowther C. Women's views and knowledge regarding healthcare seeking for gestational diabetes in the postpartum period: a systematic review of qualitative/survey studies. Diabetes Res Clin Pract 2015;110:109-22. [PubMed] [CrossRef]

12. Campbell S, Roux N, Preece C. Rafter E, Davis B, Mein J, et al. Paths to improving care of Australian Aboriginal and Torres Strait İslander women following gestational diabetes. Prim Health Care Res Dev 2017;18:549-62. [PubMed] [CrossRef] 
13. Guo J, Chen J-L, Whittemore R, Whitaker E. Postpartum lifestyle interventions to prevent type 2 diabetes among women with history of gestational diabetes: a systematic review of randomized clinical trials. J Womens Health (Larchmt) 2016;25: 38-49. [PubMed] [CrossRef]

14. Metzger BE, Gabbe SG, Persson B, Buchanan TA, Catalano PA, Damm P, et al; International Association of Diabetes and Pregnancy Study Groups Consensus Panel. International Association of Diabetes and Pregnancy Study Groups recommendations on the diagnosis and classification of hyperglycemia in pregnancy. Diabetes Care 2010;33:676-82. [PubMed] [CrossRef]

15. Madendag Y, Sahin E, Madendag Col I, Sahin Eraslan M, Tayyar A, Ozdemir F, et al. The effect of hyperemesis gravidarum on the $75 \mathrm{~g}$ oral glucose tolerance test screening and gestational diabetes mellitus. J Matern Fetal Neonatal Med 2018;31:1989-92. [PubMed] [CrossRef]

16. Ekelund M, Shaat N, Almgren P, Groop L, Berntorp K. Prediction of postpartum diabetes in women with gestational diabetes mellitus. Diabetologia 2010;53:452-7. [PubMed] [CrossRef]

17. Chiasson JL, Josse RG, Gomis R, Hanefeld M, Karasik A, Laakso M; STOP-NIDDM Trail Research Group. Acarbose for prevention of type 2 diabetes mellitus: the STOPNIDDM randomised trial. Lancet 2002;359:2072-7. [PubMed] [CrossRef]

18. DREAM (Diabetes REduction Assessment with ramipril and rosiglitazone Medication) Trial Investigators; Gerstein HC, Yusuf S, Bosch J, Pogue J, Sheridan P, Dinccag N, et al. Effect of rosiglitazone on the frequency of diabetes in patients with impaired glucose tolerance or impaired fasting glucose: a randomised controlled trial. Lancet 2006;368(9541):1096-105. [PubMed] [CrossRef]

19. Knowler WC, Barrett-Connor E, Fowler SE, Hamman RF, Lachin JM, Walker EA, et al.. Reduction in the incidence of type 2 diabetes with lifestyle intervention or metformin. $\mathrm{N}$ Engl J Med 2002;346:393-403. [PubMed] [CrossRef]

20. Werner EF, Has P, Kanno L, Sullivan A, Clark MA. Barriers to postpartum glucose testing in women with gestational diabetes mellitus. Am J Perinat 2019;36:212-8. [PubMed] [CrossRef]

21. Korkmazer E, Arslan E, Akkurt Ö, Temur M, Cift T, Üstünyurt E. Postpartum glucose tolerance test application rates and non-application causes in gestational diabetes mellitus cases. Perinatal Journal 2018;26:69-73. [CrossRef]

22. Bennett WL, Chang HY, Levine DM, Wang L, Neale D, Werner EF, et al. Utilization of primary and obstetric care after medically complicated pregnancies: an analysis of medical claims data. J Gen Intern Med 2014;29:636-45. [PubMed] [CrossRef]

23. Conway DL, Langer O. Effects of new criteria for type 2 diabetes on the rate of postpartum glucose intolerance in women with gestational diabetes. Am J Obstet Gynecol 1999;181:610 4. [PubMed] [CrossRef]

24. Buchanan TA, Xiang A, Kjos SL, Lee WP, Trigo E, Nader I, et al. Gestational diabetes: antepartum characteristics that predict postpartum glucose intolerance and type 2 diabetes in Latino women. Diabetes 1998;47:1302-10. [PubMed] [CrossRef]

25. Bernstein JA, McCloskey L, Gebel CM, Iverson RE, LeeParritz. Lost opportunities to prevent early onset type 2 diabetes mellitus after a pregnancy complicated by gestational diabetes. BMJ Open Diabetes Res Care 2016;17:e000250. [PubMed] [CrossRef]

26. Ferrara A, Hedderson MM, Albright CL, Ehrlich SF, Quesenberry Jr CP, Peng T, et al. A pregnancy and postpartum lifestyle intervention in women with gestational diabetes mellitus reduces diabetes risk factors: a feasibility randomized control trial. Diabetes Care 2011;34:1519-25. [PubMed] [CrossRef]

27. Blatt AJ, Nakamoto JM, Kaufman HW. Gaps in diabetes screening during pregnancy and postpartum. Obstet Gynecol 2011;117:61-8. [PubMed] [CrossRef]

28. Hunt KJ, Conway DL. Who returns for postpartum glucose screening following gestational diabetes mellitus? Am J Obstet Gynecol 2008;198:404e1-6. [PubMed] [CrossRef]

29. Stasenko M, Liddell J, Cheng YW, Sparks TN, Killion M, Caughey AB. Patient counseling increases postpartum followup in women with gestational diabetes mellitus. Am J Obstet Gynecol 2011;204:522.e1-6. [PubMed] [CrossRef]

30. Mendez-Figueroa H, Daley J, Breault P, Lopes VV, Paine V, Goldman D. Impact of an intensive follow-up program on the postpartum glucose tolerance testing rate. Arch Gynecol Obstet 2014;289:1177-83. [PubMed] [CrossRef]

Bu makalenin kullanım izni Creative Commons Attribution-NoCommercial-NoDerivs 3.0 Unported (CC BY-NC-ND3.0) lisansı aracılığıyla bedelsiz sunulmaktadır. / This work is licensed under the Creative Commons Attribution-NonCommercial-NoDerivs 3.0 Unported (CC BY-NC-ND3.0) License. To view a copy of this license, visit http://creativecommons.org/licenses/by-nc-nd/3.0/ or send a letter to Creative Commons, PO Box 1866, Mountain View, CA 94042, USA. 